\title{
Improvement of Social Science Learning Result Using Index Card Match Learning Model
}

\author{
Devi Afriyuni Yonanada \\ Majalengka University, Majalengka, Indonesia \\ deviyonanda1990@gmail.com
}

\begin{abstract}
Problems to be researched is how index card match learning model usage in learning process of Social Science for grade V SDN Krangkeng IV Elementary School of Indramayu. And how is the development of Social Science Learning result in students of grade V SDN Krangkeng IV Elementary School of Indramayu by using index card match learning model. The research uses Action Research, which is one of problem solving uses real action and ability process in detecting and solving problems. Design uses in this research is Classroom Action Research using Kemis and McTaggart model. Research phases are done in two cycles. Each cycle consisted of planning, application, research, and reflection. Learning result shows that indeks card match learning model would be able to improve learning result of students in Social Science Learning. It is found that the average of learning result reached improvement in Cycle I, learning completeness reached $64.4 \%$ while in Cycle II, students' learning result reached $82.1 \%$. That improvement proved that index card match learning model is able to improve learning result of students in Social Science Learning.
\end{abstract}

Keywords: learning result, index card match learning model, social science learning

\section{INTRODUCTION}

Social Science (IPS) is one of subjects that must be existed and taught in schools. The subject is one important thing of the other various existing subjects, because it teaches about social events occurring in society and also the important histories, so that students can conceive the concepts related to everyday life. Hopefully, by studying IPS students can conceive well the social relations between people and the surrounding environment. In the opinion of Trianto [6] it is explained that Social Science (IPS) is a combination of geography, history, economics, law and politics, citizenship, sociology elements, and even the fields of humanities, education and religion.

The main objective of Social Science learning is to develop the potential of students to be sensitive to social problems that occur in their society, have a positive mental attitude towards the improvement of all the inequalities that occur, and to be skillful to resolve every problem that happens either to themselves or to their society [6]. That main objective can be realized if the potential development of students can be empowered well. The potential development of students that can be empowered is by planning, implementing, assessing and supervising, so that it can be effected effectively and efficiently [6]. It is expected that the potential development of students with the material contained in IPS can be applied the knowledge gained when later they entered to their life in a society, such as interacting with friends, teachers, parents and others around them.

The subject that must be lerned and pursued by students is more difficult because the material range contained in IPS is too broad in the learning process while the time provided is not enough to fulfill it. IPS lesson is still in the concept of memorizing, so the students find it is difficult to absorb the contents of the material. Sapriya [4] states IPS subject is designed to develop knowledge, understanding, and analytical skills on the social conditions of a dynamic society.

The result of the research at SDN Krangkeng IV in class V semester I of academic year 2016/2017 is concluded from the information explained by the homeroom of class $\mathrm{V}$ by conducted an interview on July 23, 2016. It was stated that the difficulty faced by the students in IPS lesson was the difficulty of understanding the contents of the material taught, so in the classroom, the students were less concentrated and felt bored. Based on the result of the study data obtained by the researcher from the interview with the homeroom on July 23, 2016, it is known that the learning mastery obtained by the students was still much below 70 , about $37 \%$ of students who were not passed and $63 \%$ (attached) which passed from classical completeness of $75 \%$ while the Minimization Completeness Criteria (KKM) established by schools for IPS is 70 .

The condition was caused by the concept of IPS lesson that is still in the concept of memorizing that makes the students feel difficulty and bored in following the learning process. This is a problem that must be solved. In response to such condition, the homeroom who also as a lesson teacher did some handling as an effort to improve the students' learning results, such as: (1) gave exercises to make the students always remember the material that had been given; (2) gave the students a conclusion of material to read at home so that they feel easier to learn; (3) asked the students to make a recap during the learning process; and (4) gave some homework. However, there were still many students' learning results that were under the Minimization Completeness Criteria (Kriteria Ketuntasan Minimal / KKM).

The problem of the condision above needs to be solved in determining the appropriate learning so that IPS lesson not always uses the concept of memorizing, but uses a concept that can be conduceted by remembering and building as well as solving the difficulty of understanding the material and still considering the condition in the classroom. It is intended to obtain the right learning method for all students. The general method mentioned that the function of teaching methods in the whole teaching system is how the tool can achieve the teaching objectives. One of the learning strategies that can be applied is the use of learning models that can create a 
fun atmosphere by playing and also learning with the educator as a facilitator that makes students not bored and enthusiastic during the learning process. One of the learning models that can be applied is the index card match. The implementation of the learning model that is part of active learning is looking for a card pair, so that learning is not boring. This allows students to understand the material presented by the teacher.

Active learning according to Silberman means that students would learn to express their ideas by solving classroom problems and apply what they learned in class with their teachers [1]. Active learning is learning quickly and fun in the classroom. Active learning is also a learning that allows students to gain their own knowledge without having to get a lecture from their teacher. Therefore, students must be active in answering, asking and doing themselves so that the knowledge they get is from them not from other people or teachers. Active learning enables students to gain their own knowledge so that they will not easily forget what they are doing, which in turn will affect their learning results.

The explanation above states that the implementation of index card match learning model is expected to increase the students learning activities, because this learning model allows students to be the central of learning process in the classroom. Students no longer receive information provided by the teacher. Students look for pairs of cards containing questions and answers with prior attention to the instructions conveyed by the teacher. This kind of learning model is not only useful for improving student activity, but also can recall the material that has been presented, but in a fun and exciting way [5]. So this learning model is expected to improve students' learning results. Students gain knowledge not only from their teachers, but also from their own learning experience so at the end result of this learning, the index cards match learning model can improve the students' learning results.

\section{METHODS}

This research used the type of action research, i.e. one of the problem solving strategies that takes a real action and the process of detecting and solving problems. This research used the type of action research conducted by the educator who as well as the researcher in their class or together with others (collaboration) by designing, implementing and reflecting collaborative and participative actions aimed at corecting or improving quality of the learning process in the classroom through a particular action in a cycle [3]. Lewin suggests that action research is a process of developing reflection thinking power, discussion and decision-making as well as an action by a group of ordinary people who participate in a research on personal difficulties that they have [2].

The research design used was Classroom Action Research design (Penelitian Tindakan Kelas / PTK). In the principle, PTK or CAR (Classroom Action Research) is intended to address various problems within the class. While the approach used in this research was a qualitative approach because this research was in accordance with the characteristics of qualitative research (Sudjana, 2008), included: (1) used the natural environment as a source of direct data; (2) analytical descriptive; (3) research pressure existed on the process not on the result; (4) inductive; and (5) made the meaning became the priority. Qualitative approach in this research was used to get in-depth data, a data that contains a meaning (real data) was a clear picture of the class situation and student behavior during the learning process.

In this research, it was used the cycles according to Kemmis and Taggart [2]. The cycle model according to Kemmis is actually almost the same as the others, however, the process of action and observation are made together. The classroom action research uses four components, includes: (1) planning; (2) action; (3) observation; and (4) reflection. Planning it is a plan to test empirically the hypothesis that has been determined. The planning stage is the stage where the researcher prepares the things needed for the research implementation phase. The stages of planning undertaken by researcher were as follows: Created a learning design in the form of Learning Implementation Plan (Rencana Pelaksanaan Pembelajaran / RPP) with the material about HinduBuddhist and Islamic historical figures, prepared the media in the form of color papers containing questions and answers that will be used in the learning process and examples of the historical figures of HinduBuddhism and Islam pictures, created learning scenarios using the index card match learning model, made observation sheet i.e. learning process implementation and observation of student process evaluation, and designed the evaluation tool to know the improvement of IPA learning result on the material about changes in the physical environment.

Acting (action) this stage is an implementation of all the plans made. At this stage the researcher conducted the learning in accordance with the Learning Implementation Plan (RPP) that has been prepared, collected and submited the test results data, and student worksheets (Lembar Kerja Siswa / LKS). The RPP and Syllabus that conducted in this implementation stage were the RPP that was in the implementation of learning using the cards as the media of learning, the outline of learning implementation was listed in the syntax of index card match learning model, as follows: the students were given the IPS material about the Hindu-Buddhist and Islamic historical figures, the students were given an explanation of the index card match learning model and the rules of the game, the students are given index cards that had been randomized by the teacher, the students then looked for pairs of papers they had, after finding the pairs, asked them to sit on each single bench, after all found their respective pairs, the next step was to test the truth or accuracy of the pairs, the students with the teacher discussed the activities to find the pair index cards that had been separated, the students did a test individually to know the understanding of the concept about the material of changes in the physical environment, then the students wrote down the results obtained on the answer sheets provided by the teacher. 
Observing (observation), observation activity is held to collect information about the learning process conducted in accordance with the procedures that have been determined. In conducting the observation, it had been assisted by a class teacher in class $\mathrm{V}$ and 1 observer who is the researcher's colleague. The observation was conducted by observing the implementation of learning that took place at each meeting whether it was done or not by giving time to fulfill the column provided. The observation was conducted with several observed aspects as follows: cooperation activity, learning implementation used the Index Card Match learning model which contained the teacher and students activities (student responses, student attendance). The observation was conducted by the tutor teacher or homeroom in accordance with the observation instruments provided by the researcher.

Reflecting (reflection) is a stage of processing data obtained at the time of observation. After conducting a series of activities, at the end of the cycle, the researcher and the homeroom reflected collaborately included: (1) observed the learning technique that had been done; (2) identified the factors that hamper and facilitate the researcher in conducting the learning using index card match model; (3) formulated the action to be conducted next; and (4) arranged the implementation plan of using index card match learning model to be executed in the cycle II. In this research, it was used 2 cycles because only in cycle II the purpose of this research has been achieved, i.e. classical completeness of $75 \%$ of all students total in the class.

\section{RESULT AND DISCUSSION}

This research used 2 cycles. In the cycle I the researcher used 1 meeting and and it was got the result that had not reached the objectives of the research yet, so it was continued in cycle II by looking at the reflection on cycle I. On the implementation of cycle II the objectives of this research had been reached that was to achieve classical completeness of at least $75 \%$ of the students total in the class.

From the result of cycle I, it was known that the students' classical completeness was $64.4 \%$ of passed student and $35.6 \%$ of failed students. From the analysis of each question that was conducted in the cycle I, it can be known that only a few students were able to answer the question number 7 i.e. A question of column that made the students feel confused to answer it, so in the cycle II the question was changed into an essay model that was more easily understood by the students. This change of the question form was appropriate to be conducted because there was an increasing percentage to answer the question in cycle II. The Classical completeness in cycle II became $82.1 \%$ passed student and $17.9 \%$ failed student.

In the results of the process assessment analysis in cycle I, there were still some activities that are low on the aspect of cooperation and responsible. This was because the students were not familiar with the learning model that required them to be active in the learning process in the classroom. The students tend to be embarrassed when performing the index cards they find with a partner. The students were less enthusiastic about delivering the cards found together in the classroom. The competition pattern was included in cycle II to increase the spirit of students in finding the index card pairs and foster cooperation between each pair to quickly find and paste the index card pairs on the board provided. The result was the percentage of cooperation and responsibility aspects increased significantly, in cycle I the percentage of cooperation was $64.4 \%$ and the responsible was $61.5 \%$, while in cycle II the percentage of cooperation and responsible increased into $77.9 \%$.

The implementation of index card match learning model could improve the students' learning result in the material about historical figures of HinduBuddhist and Islam because this learning model made the students happy by the element of the game in it. However, the use of index card match learning model was difficult to be applied in the students who usually use the lecture method only, so that when the students pair up in accordance with the index card match obtained, the students could not cooperate with the pair of cards. So it was needed for a variation of learning by adding elements of competition in it so that the students were more eager to find the index card pairs.

This learning model could recall the material presented by the teacher in a fun way of playing a pair of separated index cards between questions and answers about the material taught during initial core activities so that the students not only received the knowledge from the teacher but also found their own knowledge that gained so that the students more easily understood the material because of experiencing and doing it themselves. This was accordance with the opinion of a Chinese philosopher Confucius states that: "what I hear, I forget"; "what I see, I remember"; and "what I do, I understand" [5]. This opinion is corroborated by Bonwell and Eison provides several examples of active learning, one of which is paired learning [1].

Based on the result of this research, it was known that learning by using index card match learning model could improve students' learning result about the material of Hindu-Buddhism and Islamic historical figures. This could be seen from the result of students learning in the learning process in cycle I and cycle II. The number of students who scored below the KKM research was 70. In the cycle I there were $64.4 \%$ passed students and $35.6 \%$ failed students. The students' learning result had increased in the cycle II which was the students who passed were $82.1 \%$ and the students who failed were $17.9 \%$. Here is a graph of the students' learning result improvement using the index card match learning model. From the acquisition of students' scores, it can be seen that students' learning result had increased significantly through the learning by applying the index card match learning model and supported by the appropriate learning method. So it can be said that the application of index card match learning model can improve the learning result of the students class V SDN Krangkeng IV Indramayu in the material about Hindu-Buddhist and Islam historical figures. The following table shows the 
improvement of students' learning result in cycle I and cycle II.

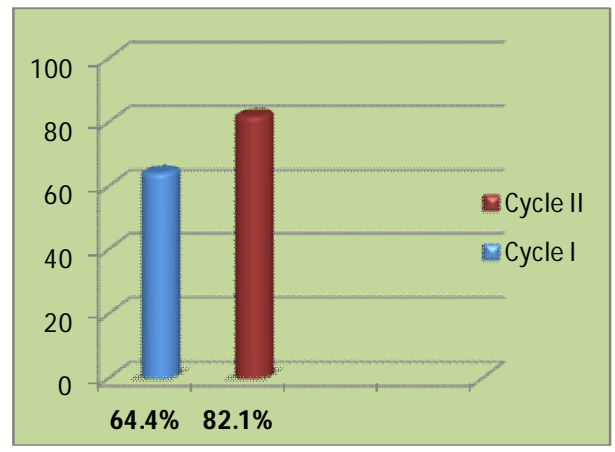

Figure 1

Percentage Graph of Cycle I and Cycle II

In the cycle I, the implementation of learning using index card match model was not fully implemented, because the researcher's lack of implementing the model, it was in the activity to explain the steps conducted by the resesrcher after presenting the material about changes in the physical environment. In the cycle II the implementation of index card match model was implemented well so that the learning was also running well as well as getting a significant increase of the students' learning result.

\section{CONCLUSIONS}

Based on the process and the result of the research, the actions obtained in this research can be put forward several conclusions as follows:

1. The application of Index Card Match learning model to the material of Hindu-Buddhist and Islamic historical figures to the students of class $\mathrm{V}$ SDN Krangkeng IV Indramayu through several steps as follows: (a) explained the steps of learning model using index card match model. In this activity the teacher explained to the rules of the game the students that must be done by them; (b) shuffled the question cards and answer cards; (c) distributed the index cards separately to the students; (d) the students looked for the pair cards that had been distributed, in this activity the teacher guided the students not to compete each other cards, in the implementation there was also an element of competition so that students were more eager in finding the pair of cards; (e) the students sat in pairs according to the pair of cards obtained; (f) alternately the pairing presented the index cards obtained; and (g) discussed the results of activities that had been conducted. The researcher also added a pattern of competition in improving the spirit of the students in finding pairs of index cards.

2. The improvement of learning result in IPS about Hindu-Buddhist and Islamic historical figures using the index card match learning model to the students class V SDN Krangkeng IV Indramayu could be seen in the increasing number of passed students from the results of cycle I were $64.4 \%$ thorough and the failed students were $35.6 \%$, because the students were not given time to re-read the material delivered and the absence of competition in finding separate index card pairs distributed by the teacher. While in cycle II, it had a significant increase that was the percentage of classical completeness, so that it became $82.1 \%$ of pased students and only $17.9 \%$ of students who are not passed.

Based on the research conducted using the index card match learning model then there are some suggestions that can be used as the improvement in further research. The suggestions are as follows:

1. The use of media should be more concerned in order to be better to help teachers delivering the material.

2. Time management of the core activities affects the students' learning result on answering the questions given individually. So that the students have the opportunity to record the material presented by the teacher to be used as a reference to study at their home in order to be able to answer the questions given individually.

3. Based on the result of the research, it is provided a description that the application of index card match learning model can be used as an alternative learning model that can improve students' learning result, especially on IPS about Hindu-Buddhist and Islamic historical figures. It is recommended for teachers to use this model as an alternative learning model that will be used to improve students' learning result. this model also allows to be used on other suitable subjects using paired models to recall material presented, in addition, the implementation of this model is not only used in elementary school level but also in higher school levels.

\section{REFERENCES}

[1] Asmani, J. M. 2012. 7 Tips Aplikasi Pakem. Yogyakarta: Diva Press.

[2] Herawati, S., Chotimah, H., and Sari, Y. D. 2008. Penelitian Tindakan Kelas Sebagai Sarana Pengembangan Keprofesionalan Guru dan Calon Guru. Malang: Bayumedia Publishing.

[3] Kunandar. 2011. Langkah Mudah Penelitian Tindakan Kelas Sebagai Pengembangan Profesi Guru. Jakarta: PT Rajawali Pers.

[4] Sapriya. 2009. Pendidikan IPS. Bandung: PT Remaja Rosdakarya.

[5] Silberman, M. 2011. Active Learning 101 Cara Belajar Siswa Aktif. Bandung: Nuansa.

[6] Trianto. 2007. Model Pembelajaran Terpadu dalam Teori dan Praktik. Jakarta: Prestasi Pustaka. 